\title{
Molecular and Phenotypic Diversity of Traditional European Plum (Prunus domestica L.) Germplasm of Southern Italy
}

\author{
Rosanna Manco, Boris Basile $\oplus^{\circ}$, Claudio Capuozzo, Pasquale Scognamiglio, Marcello Forlani, \\ Rosa Rao and Giandomenico Corrado * \\ Dipartimento di Agraria, Università degli Studi di Napoli Federico II, via Università 100, 80055 Portici (NA), Italy \\ * Correspondence: giandomenico.corrado@unina.it; Tel.: +39-081-2539294
}

Received: 5 June 2019; Accepted: 26 July 2019; Published: 30 July 2019

check for updates

\begin{abstract}
The European plum (Prunus domestica L.) is a worldwide distributed tree species. Italy has an ample number of traditional varieties, but many are neglected and at risk of extinction. This germplasm is still cultivated in rural areas in spite of the EU-28 crisis of the stone fruit sector. Traditional European plum varieties remain poorly characterized, strongly limiting their promotion in local markets, use for farm diversification, and exploitation for local gastronomic products. In this study, we carried out an investigation of the morphological and genetic diversity present in an ex-situ collection of 29 traditional varieties of P. domestica of the Campania region (Southern Italy). The combination of five continuous and five categorical fruit traits allowed us to phenotypically distinguish all the varieties. Similarly, the Simple Sequence Repeats (SSRs) employed (five genomic and five deriving from Expressed Sequence Tags) identified a unique molecular profile for each variety. Moreover, the data indicated that the phenotypic and molecular investigations provided different clustering, suggesting that the two analyses sampled different sources of diversity. The number and the distribution of the scored phenotypes as well as the indices of genetic diversity imply the presence of a wide-ranging variation, which may sustain the development of high-value, niche market products. Our work provided evidence that the implementation of measures for a combination of ex-situ and on-farm conservation of traditional European plum varieties should be preferred to avoid the loss of an ample diversity.
\end{abstract}

Keywords: molecular markers; SSR; germplasm; conservation; diversity; morphologic traits; plant genetic resource

\section{Introduction}

Plums are a group of stone fruits with edible fleshy mesocarp produced by different species of the large, globally distributed genus Prunus (Rosaceae) [1]. The most important cultivated varieties belong either to P. domestica (European plum) or P. salicina (Asian or Japanese plum) [1]. European plum is a hexaploid $(2 n=6 x=42)$ species native to Asia and probably spread into Western civilization during the Roman Empire [2]. The mild Mediterranean climate and the varied soils and farming conditions favored the diffusion of plum in Italy and this species has experienced a considerable diversification. For instance, the presence of an ample selection of fruits was documented already in the 17th century [3]. In Italy, the plum cultivation almost certainly reached its peak after WWI, in conjunction with the first introduction of non-Italian cultivars. However, after WWII, the cultivation of the plum did not expand and in few decades, it became marginal compared to the apple, pear, and peach [4]. More crucially, the rich Italian germplasm (estimated in hundreds of varietal names) has been gradually replaced by improved P. salicina cultivars (mainly of American origin) because of their 
pomological features (e.g., fruit color, shape, size and yield) and adaptability to early production and post-harvest (e.g., handling, transport and refrigeration) [5]. Currently, plum cultivation in Italy, which is in the top 10 producing countries (FAO, 2016), is present essentially in two regions (Emilia-Romagna and Campania), with around $75 \%$ of the production represented by Japanese plums [6]. In these areas, farmers still maintain in cultivation traditional European varieties for local fresh markets and for processing (jams and dried or canned plums). Traditional cultivars are receiving growing attention because of their perceived value and reputation deriving from their geographical origin. Product differentiation and diversification (e.g., goods with unconventional characteristics, such as organic foods, PDO and PGI products) can provide a competitive advantage [7], and in some settings, European plum varieties were effective in improving profitability and sustainability [8]. Although yield may not always be satisfactory, the locally adapted traditional varieties are appreciated for their superior flavor and taste [9]. Moreover, these varieties are considered to be more amenable to low-input agriculture, better suited for traditional farming (e.g., low planting density), and more adapted to local conditions than Japanese plums. The latter generally suffers from insufficient winter hardiness and limited soil adaptability [10]. For instance, European plums are deemed more appropriate for a humid environment and less prone to disease. Especially for the warmer areas of Southern Italy, there is currently an unmet need of late-flowering varieties to reduce the risk of spring frost damage in the face of climate change [10,11]. In recent times, traditional plums have been considered as a viable alternative following the crisis in the peach and nectarine sector that hit Italy, Spain, and Greece (Reg. EU 2017/1165) [12], although this increase is mainly restricted to fruit production with organic farming methods. The European germplasm for professional agriculture is more limited compared to Japanese plums $[1,13]$. However, the potential of traditional varieties to diversify the plum sector, support local producers and promote traditional gastronomic products (e.g., no-sugar added plum jams; [14]) has been unexplored due to the lack of information on available plant material.

The primary policy goal for conservation and exploitation of agricultural biodiversity should focus on the assessment of the existing diversity [15], which often represents a major constraint [16]. This effort is essential to prospect strategies for the implementation of adequate on-farm conservation schemes and it is a prerequisite for the utilization of plant genetic resources for sustainable agriculture [16]. The evaluation of morphological traits is an established and important method for the description and identification of plum varieties $[13,17,18]$. In addition, DNA analysis provides information that is independent of environmental effects. In plums, DNA analysis has proved to be valuable for map-based cloning [19] as well as the study of genetic diversity, population structure, and phylogenetic relationships [20-22]. Moreover, the molecular analysis of plant genetic resources is also useful to identify duplicate accessions in core collections or possible cases of homonymy and synonymy in traditional tree varieties $[23,24]$.

The characterization of the Italian germplasm of European plum at both the molecular and morphological level has received little attention, despite the long history of cultivation, the large number of accessions and the presence of some well-known local varieties that excel for fruit quality [25]. The aim of this study was to characterize and evaluate the diversity of traditional European plums that are cultivated in the Campania region (Southern Italy) using morphological and molecular data, in order to provide experimental based evidence for the implementation of measures to safeguard this agricultural biodiversity.

\section{Materials and Methods}

\subsection{Plant Material}

The investigation was performed on 29 Prunus domestica $L$ varieties. The varieties (and their code) are: 'Biancolella di Ottaviano' (BIA), 'Botta a muro bianca' (BOT), 'Coglie 'e piecr nera' (synonym: 'Coglie 'e astag nera'; 'Coglie 'e piecuro nero') (COG), 'Core' (COR), 'Del Carmine' (DEL), 'Di Spagna' (syn: 'Spagna') (DIS), 'Fele' (FEL), 'Fiocco bianco' (FIO), 'Genova giallo-verde' (GEN), 'Marchigiana' 
(MAR), 'Mbriaca' (MBR), 'Melella' (MEL), 'Occchio di bue' (OCC), 'Pannanorese' (syn: 'Pannaranese') (PNN), 'Pappagona gialla' (PPG), 'Pappagona verde' (PPV), 'Pazza di Somma' (PAZ), 'Pezza rossa' (PEZ), 'Preta e' zucchero' (syn: 'Meraviglia') (PRE), 'Prunarina' (syn: ‘Prunarinia') (PRU), 'Rachele' (RAC), 'Riardo' (RIA), 'Santa Maria ' (SAM), 'Santa Paola' (SAP), 'San Rafele' (SAR), 'Scarrafona' (SCR), 'Scauratella' (SCU), 'Turcona' (TUR) and 'Uttaiana' (syn. 'Ottaviana) (UTT). The germplasm includes both autochthonous material and ancient introductions, and varieties were selected among the most diffused traditional plums in the Campania region (Southern Italy). Samples were obtained from the field collection of the "Azienda Agricola Sperimentale Regionale Improsta" of the "Centro per la Ricerca Applicata in Agricoltura” (C.R.A.A.).

\subsection{Analysis of Morphological Data}

During 2011, five continuous and five categorical fruit traits were recorded on thirty typical, marketable fruits harvested on five healthy trees per variety (six fruits per tree). The continuous fruit traits were the following: fruit fresh weight (g/fruit), fruit length $(\mathrm{mm})$, width $(\mathrm{mm})$, fruit shape index (a dimensionless parameter calculated as the fruit length to fruit width ratio) and soluble solids content ( ${ }^{\circ}$ Brix); whereas the categorical fruit traits were the following: fruit skin color, color of flesh, fruit shape (in lateral view), degree of adherence of stone to flesh and general stone shape (in lateral view). Phenotypes were categorized according to the guidelines for the conduct of tests for distinctness, uniformity and stability (DUS) of The International Union for the Protection of New Varieties of Plants (UPOV, Geneva, Switzerland) document TG/41/5 (2002). Soluble solids content was measured with a digital refractometer (HI96811, Hanna Instruments, Carrollton, TX, USA).

For quantitatively scored variables, the significance of the differences between varieties were assessed by a one-way ANOVA test using the Duncan's multiple range test as a post-hoc test for mean separation, using SPSS 20 (IBM Statistics). Correlation between quantitative variables was studied with the Pearson's coefficient and illustrated using the corrplot R package [26]. For hierarchical clustering based on both continuous and categorical morphological data, we calculated pairwise distances with the Gower's coefficient [27] without assigning a weight to variables, using the R package StatMatch [28]. Considering that data are on different scales, continuous variables were first standardized using the 'scale' function implemented in R [29]. Hierarchical clustering was performed on scaled distances using the unweighted pair-group method with arithmetic averages (UPGMA) algorithm in R [29].

\subsection{Molecular Analysis}

Total DNA was isolated from young leaves using a previously reported procedure for vegetable fruits [30] and quantified by agarose gel-electrophoresis. Varieties were analysed in duplicates (two plants per variety). Ten nuclear Simple Sequence Repeat (SSR) loci (five from EST-libraries and five from genomic libraries) were used for Polymerase Chain Reaction (PCR) amplification and their main features (e.g., primer sequences and annealing temperature, Ta) are reported in Supplementary Table S1 [31-35]. The PCR reaction was assembled in a $25 \mu \mathrm{L}$ volume with $100 \mathrm{ng}$ genomic DNA as described [30]. The amplification conditions were: one denaturing step at $94{ }^{\circ} \mathrm{C}$ for $5 \mathrm{~min}$, followed by 35 cycles of $94{ }^{\circ} \mathrm{C}$ for $45 \mathrm{~s}, \mathrm{Ta}^{\circ} \mathrm{C}$ for $45 \mathrm{~s}$, and $72{ }^{\circ} \mathrm{C}$ for $1 \mathrm{~min} 30 \mathrm{~s}$. After the final cycle, a $15 \mathrm{~min}$ step at $72{ }^{\circ} \mathrm{C}$ was added. Amplification products were separated by agarose gel-electrophoresis to verify the presence of amplified fragments. For allelic discrimination, fluorescent fragments were resolved by capillary electrophoresis in an ABI Prism 3130 Genetic Analyzer system (Applied Biosystems, Foster City, CA, USA) as previously reported [36]. Raw sizes were rounded to integer and scaled according to the SSR-core motif (Supplementary Table S1), while minimizing the average offset of the alleles for each SSR within the instrumental resolution $( \pm 1 \mathrm{bp})$.

\subsection{Molecular Data Analysis}

For each SSR locus, we calculated the number of different alleles, the Shannon's information index $(-1 \times \operatorname{Sum}(\mathrm{pi} \times \ln (\mathrm{pi}))$, the observed heterozygosity $(\mathrm{Ho}$; number of heterozygotes/N) and the Expected 
Heterozygosity, also called Nei's unbiased gene diversity [37] $(n /(n-1))^{*}\left(1-\operatorname{sum}\left(p^{\wedge}{ }^{\wedge}\right)\right)$, where $n$ is number of individuals, pi the frequency of the ith allele for the population and (sum pi^2) represent the sum of the squared population allele frequencies. A Maximum Likelihood Estimation method was used to correct for the unknown dosage of the alleles. This algorithm was run separately for each locus. These calculations were carried out with the Genodive software [38]. The genotype accumulation curve was created by randomly sampling $(n=1000)$ the ten loci to create the distribution and counting the number of multiloci genotypes for an increasing number of SSRs. Pairwise genetic distances between varieties were calculated with the Bruvo's coefficient [39] using the poppr R-library [40]. Hierarchical clustering was carried out as described for the morphological data. To test the correlation between the morphological and molecular data, the two parallel matrices from independent data were compared by a Mantel test with 9999 permutations. The test statistic varies from 0 (no correspondence) to +1 (respectively, -1 ), indicating total positive (resp., negative) correspondence. Calculations and tree visualization were performed in $\mathrm{R}[29]$.

\section{Results}

\subsection{Morphological Characterization}

The result of the analysis of the quantitatively and qualitatively scored traits is presented in Table 1. Statistically significant differences among varieties were present for each of the five continuous variables. Among them, the fruit trait that displayed the largest variation was the fresh weight $(\mathrm{CV}=53.9 \%)$, followed by the shape index $(19.6 \%)$, the width $(18.9 \%)$ and the length $(18.1 \%)$. As expected, the fruit length, width and fresh weight were significantly correlated (Supplementary Figure S1). A negative correlation was present between total soluble content and fruit fresh weight $(-0.39$; $p=0.034)$.

A clear skin color (i.e., yellow and yellowish-green) was predominant (65\% of the varieties; Table S2). A larger diversity was present considering the color of flesh, for which we recorded all the different classes present in the guidelines for the conduct of DUS test for the European plum (TG/41/5). Also for this trait, a clear color was more frequent (62\% of the varieties). The most common shape in lateral view was elliptic ( $52 \%$ of the varieties).

Considering only the qualitative traits under investigation, we recorded 24 unique phenotypes for the 29 varieties. No plant had a fruit phenotype deriving from the combination of the most frequent trait for each of the categorical variables (Table S2). The most common phenotype in the germplasm was a circular fruit with red skin, orange flesh, and an elliptic, clinging stone. This combination was only present in three varieties (MAR, PRE and SAP), which are primarily discriminated taking into account fruit size.

Overall, fruit qualitative traits were highly discriminant but fruit size was needed to assign a unique phenotype to all the varieties under examination. For this reasons, in order to visualize the relations between the genotypes under investigation, we performed an agglomerative analysis using both qualitative and quantitative traits (without assigning a weight to each trait) (Figure 1). A clear clustering according to a specific fruit trait was not evident, which suggests that the morphological diversity is ample and distributed among the varieties. 
Table 1. Morphological analysis of the 29 P. domestica varieties. For quantitative traits, different letters represent statistically different groups. See Supplementary

Figure $\mathrm{S} 2$ for examples of the color of the fruit flesh and skin..

\begin{tabular}{|c|c|c|c|c|c|c|c|c|c|c|c|c|c|c|c|}
\hline \multirow{2}{*}{$\begin{array}{l}\text { Code } \\
\text { BIA }\end{array}$} & \multicolumn{2}{|c|}{$\begin{array}{c}\text { Fruit Fresh } \\
{\text { Weight }\left(\mathrm{g} \text { fruit }^{-1} \text { ) }\right.}^{\text {a }}\end{array}$} & \multicolumn{2}{|c|}{$\begin{array}{l}\text { Fruit Length } \\
(\mathrm{mm})\end{array}$} & \multicolumn{2}{|c|}{ Fruit Width (mm) } & \multicolumn{2}{|c|}{ Fruit Shape Index } & \multicolumn{2}{|c|}{$\begin{array}{l}\text { Soluble Solids } \\
\text { Content }\left({ }^{\circ} \text { Brix) }\right.\end{array}$} & \multirow{2}{*}{$\begin{array}{c}\begin{array}{c}\text { Skin } \\
\text { Color }\end{array} \\
\mathrm{Y}\end{array}$} & \multirow{2}{*}{$\begin{array}{c}\begin{array}{c}\text { Flesh } \\
\text { Color }^{2}\end{array} \\
\mathrm{Y}\end{array}$} & \multirow{2}{*}{$\begin{array}{c}\begin{array}{c}\text { Fruit } \\
\text { Shape }^{3}\end{array} \\
\text { Elli }\end{array}$} & \multirow{2}{*}{$\begin{array}{c}\begin{array}{c}\text { Stone Adherence } \\
\text { to Flesh }\end{array} \\
\text { S-C }\end{array}$} & \multirow{2}{*}{$\begin{array}{r}\begin{array}{r}\text { Stone } \\
\text { Shape }\end{array} \\
\text { N-E }\end{array}$} \\
\hline & 26.4 & 1 & 45.3 & hi & 32.0 & nop & 1.41 & e & 16.9 & il & & & & & \\
\hline BOT & 40.6 & $\mathrm{~g}$ & 43.0 & $\operatorname{lmn}$ & 40.2 & fgh & 1.07 & $\mathrm{n}$ & 17.9 & gh & Y & Y & Circ & $\mathrm{S}-\mathrm{C}$ & E \\
\hline $\mathrm{COG}$ & 75.2 & $\mathrm{~b}$ & 60.3 & $\mathrm{a}$ & 47.6 & bc & 1.27 & hi & 18.3 & gh & $\mathrm{R}$ & $\mathrm{R}$ & Circ & $\mathrm{C}$ & E \\
\hline COR & 97.4 & $\mathrm{a}$ & 57.8 & $\mathrm{~b}$ & 54.3 & a & 1.06 & no & 14.5 & $\mathrm{qr}$ & $\mathrm{R}$ & $\mathrm{O}$ & Elli & $\mathrm{S}-\mathrm{C}$ & E \\
\hline DEL & 21.8 & mnop & 42.5 & $\mathrm{mn}$ & 29.6 & opq & 1.43 & de & 21.0 & $c$ & YG & $\mathrm{Y}$ & Elli & $\mathrm{S}-\mathrm{C}$ & - \\
\hline DIS & 33.0 & hi & 33.7 & $\mathrm{~s}$ & 38.5 & ghi & 0.88 & $\mathrm{t}$ & 20.4 & $\mathrm{~cd}$ & YG & $\mathrm{Y}$ & Circ & $\mathrm{F}$ & E \\
\hline FEL & 25.2 & $\operatorname{lm}$ & 39.7 & $\mathrm{pq}$ & 32.7 & mno & 1.21 & $\operatorname{lm}$ & 18.7 & $\mathrm{fg}$ & VB & $\mathrm{Y}$ & Elli & $\mathrm{F}$ & N-E \\
\hline FIO & 52.6 & de & 53.1 & $\mathrm{~cd}$ & 41.1 & efg & 1.29 & $\mathrm{gh}$ & 15.4 & nopq & $\mathrm{Y}$ & $Y$ & Elli & S-C & N-E \\
\hline GEN & 44.5 & $\mathrm{fg}$ & 41.7 & no & 41.1 & efg & 1.01 & $\mathrm{pq}$ & 19.5 & ef & YG & $\mathrm{Y}$ & Elli & S-C & N-E \\
\hline MAR & 28.7 & il & 36.4 & $\mathrm{r}$ & 35.3 & ilmn & 1.03 & op & 15.6 & nop & $\mathrm{R}$ & $\mathrm{O}$ & Circ & $\mathrm{C}$ & $\mathrm{E}$ \\
\hline MBR & 31.4 & hi & 51.4 & ef & 32.6 & mnop & 1.58 & $\mathrm{a}$ & 28.9 & $\mathrm{a}$ & YG & YG & Elli & F & N-E \\
\hline MEL & 31.9 & hi & 33.6 & $\mathrm{~s}$ & 38.4 & ghi & 0.87 & $t$ & 13.0 & $\mathrm{tu}$ & $\mathrm{R}$ & OR & Obla & $\mathrm{C}$ & N-E \\
\hline OCC & 51.9 & $\mathrm{e}$ & 42.5 & $\mathrm{mn}$ & 44.9 & $\mathrm{~cd}$ & 0.95 & $\mathrm{~s}$ & 15.3 & nopq & YG & $\mathrm{Y}$ & Circ & S-C & $\mathrm{E}$ \\
\hline PNN & 19.0 & $\mathrm{pq}$ & 40.6 & op & 28.3 & $q$ & 1.43 & de & 19.6 & def & YG & $\mathrm{Y}$ & Elli & S-C & N-E \\
\hline PPG & 20.6 & nopq & 42.5 & $\mathrm{mn}$ & 29.0 & $\mathrm{pq}$ & 1.46 & $\mathrm{~cd}$ & 18.2 & $\mathrm{gh}$ & $\mathrm{Y}$ & YG & Elli & S-C & N-E \\
\hline PPV & 41.7 & $\mathrm{fg}$ & 54.3 & c & 36.4 & il & 1.49 & $\mathrm{bc}$ & 18.7 & $\mathrm{fg}$ & YG & YG & Elli & S-C & N-E \\
\hline PAZ & 50.9 & e & 50.7 & $\mathrm{f}$ & 41.7 & defg & 1.22 & 1 & 13.1 & tu & $\mathrm{Y}$ & $\mathrm{Y}$ & Obov & S-C & E \\
\hline PEZ & 100.2 & $\mathrm{a}$ & 56.4 & $\mathrm{~b}$ & 53.8 & $\mathrm{a}$ & 1.05 & nop & 13.5 & stu & VB & $\mathrm{O}$ & Obla & $\mathrm{C}$ & E \\
\hline PRE & 40.3 & $\mathrm{~g}$ & 36.9 & $\mathrm{r}$ & 42.6 & def & 0.87 & $\mathrm{t}$ & 16.2 & $\operatorname{lmn}$ & $\mathrm{R}$ & $\mathrm{O}$ & Circ & $C$ & $\mathrm{E}$ \\
\hline PRU & 24.3 & lmno & 40.6 & op & 32.2 & mnop & 1.27 & hi & 16.8 & $\mathrm{ilm}$ & $\mathrm{Y}$ & $\mathrm{Y}$ & Elli & $\mathrm{F}$ & $\mathrm{N}-\mathrm{E}$ \\
\hline RAC & 19.9 & opq & 42.8 & $\operatorname{lmn}$ & 28.1 & q & 1.52 & $\mathrm{~b}$ & 17.9 & $\mathrm{gh}$ & YG & G & Elli & S-C & $\mathrm{E}$ \\
\hline RIA & 62.2 & c & 52.7 & de & 44.6 & cde & 1.18 & $\mathrm{~m}$ & 15.3 & opq & VB & $\mathrm{O}$ & Obov & S-C & $\mathrm{E}$ \\
\hline SAM & 24.3 & lmno & 45.9 & $\mathrm{gh}$ & 29.5 & opq & 1.56 & $\mathrm{a}$ & 18.7 & $\mathrm{fg}$ & YG & G & Elli & C & E \\
\hline SAP & 17.0 & $\mathrm{q}$ & 29.3 & $\mathrm{t}$ & 29.7 & opq & 0.99 & $\mathrm{qr}$ & 20.2 & cde & $\mathrm{R}$ & $\mathrm{O}$ & Circ & $\mathrm{C}$ & $\mathrm{E}$ \\
\hline SAR & 33.6 & $\mathrm{l}$ & 44.3 & il & 35.7 & ilm & 1.24 & il & 12.7 & $\mathrm{u}$ & YG & YG & Elli & $\mathrm{F}$ & N-E \\
\hline SCR & 31.8 & hi & 46.9 & $\mathrm{~g}$ & 34.7 & $\operatorname{lmn}$ & 1.35 & $\mathrm{f}$ & 14.9 & $\mathrm{pq}$ & VB & G & Elli & $\mathrm{F}$ & $\mathrm{E}$ \\
\hline SCU & 50.0 & $\mathrm{e}$ & 42.2 & mno & 43.7 & def & 0.97 & rs & 15.2 & opq & $\mathrm{Y}$ & Y & Circ & $C$ & - \\
\hline TUR & 32.7 & hi & 36.3 & $\mathrm{r}$ & 38.8 & ghi & 0.96 & rs & 23.5 & b & $\mathrm{Y}$ & $\mathrm{Y}$ & Oblo & $\mathrm{F}$ & N-E \\
\hline UTT & 24.8 & $\operatorname{lmn}$ & 32.5 & $\mathrm{~s}$ & 37.3 & hil & 0.87 & $t$ & 17.5 & hi & $\mathrm{Y}$ & $\mathrm{Y}$ & Obov & F & $\mathrm{E}$ \\
\hline
\end{tabular}

${ }^{1}$ Y: yellow; YG: yellowish green; R: red; VB: violet blue; ${ }^{2}$ Y: yellow; R: red; O: orange; YG: yellowish-green; OR: orange-reddish; G: green; ${ }^{3}$ Circ: Circular; Elli: Elliptic; Obla: Oblate; Oblo:

Oblong; Obov: Obovate; ${ }^{4}$ C: Clinging (adherent); S-C: Semi-Clinging (semi-adherent); F: Free (non-adherent); ${ }^{5}$ N-E: Narrow-Elliptic; E: Elliptic. 


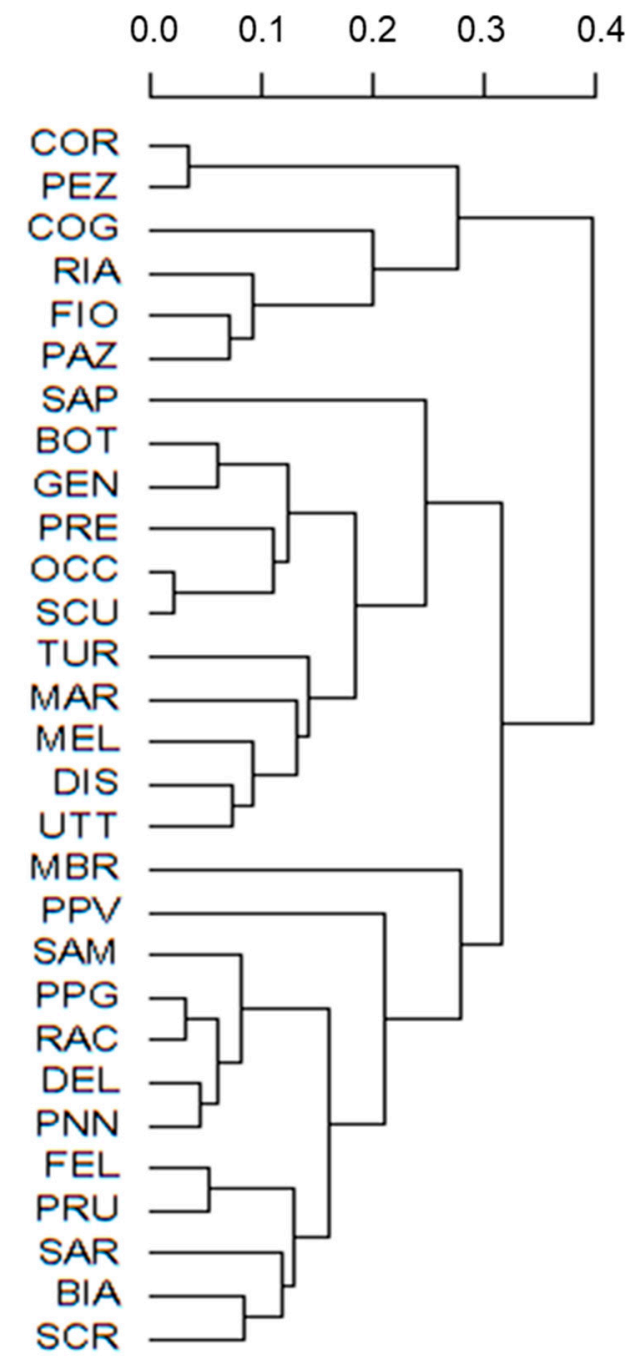

Figure 1. Cluster analysis (UPGMA algorithm based on Gower's distances from morhological traits) of the European plum varieties.

\subsection{Molecular Characterization}

For the analysis of genetic diversity, we employed 10 SSRs representatives of various repeat classes (Supplementary Table S1). All loci were polymorphic in our population and the observed different alleles of the genotypes per locus are visualized by an heatmap (Figure 2A). The number of amplified fragments never exceeded the ploidy level. 
(A)

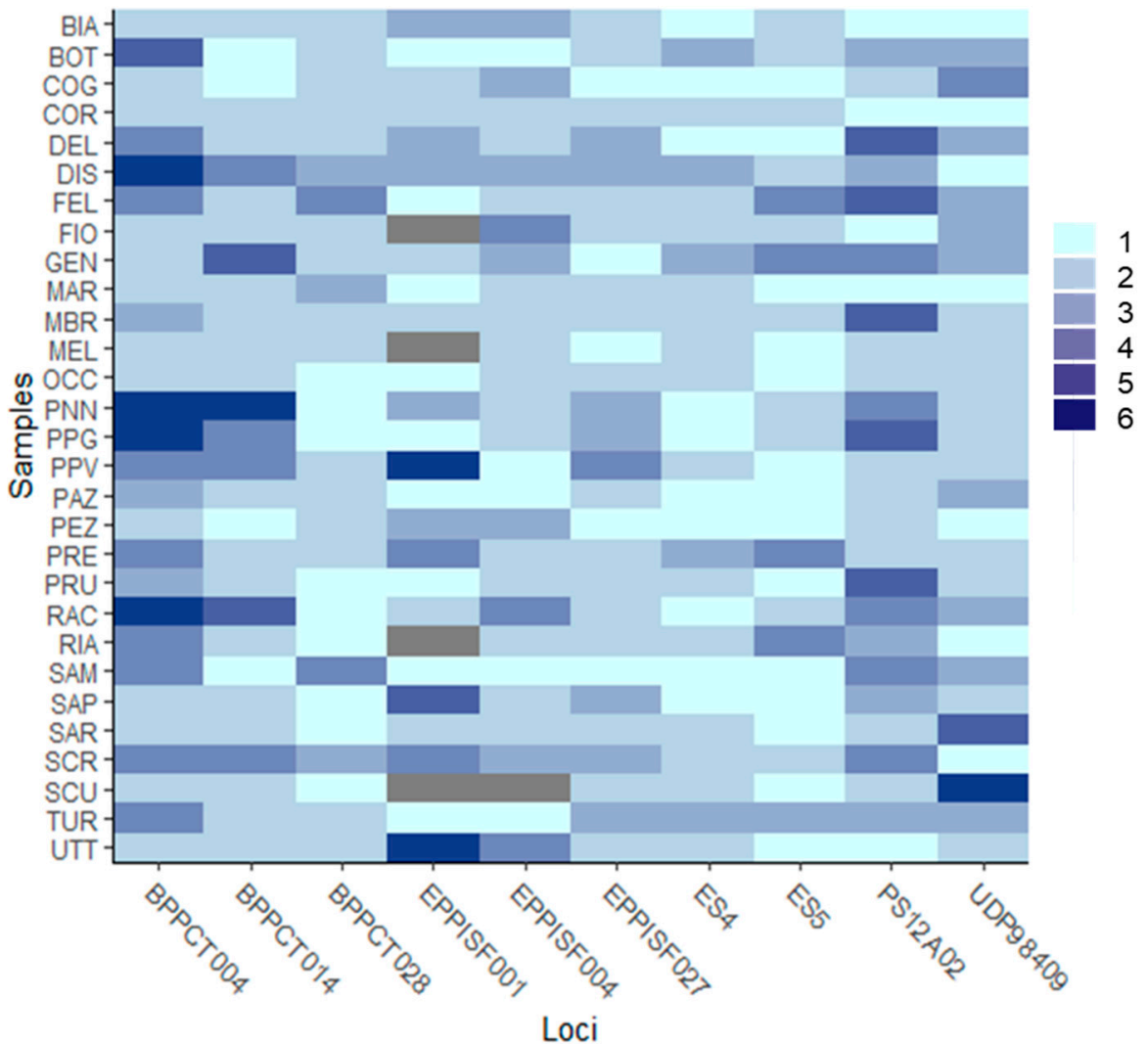

(B)

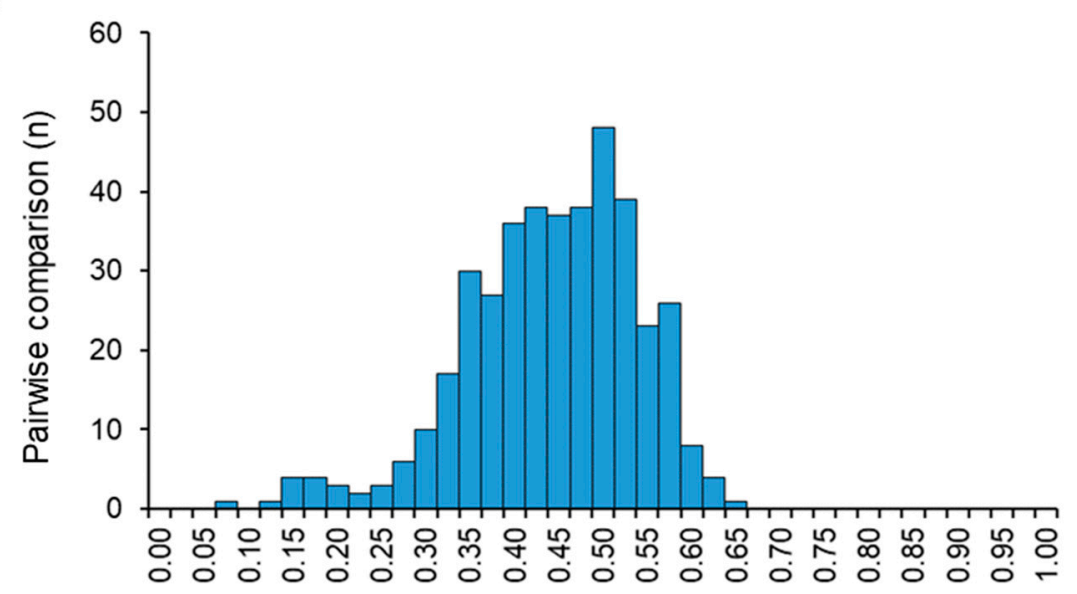

Genetic distance

Figure 2. (A) Heatmap indicating the number of different alleles at the SSR loci in the plum varieties. The color bar-scale on the right-hand side associates color intensity with the number of alleles. Grey boxes represent low-quality data (not included in the analysis). (B) Distribution of the pairwise Bruvo's genetic distances of the 29 varieties. Each bar shows the number of pairwise comparisons between varieties that have a genetic distance included in the class intervals reported on the $x$-axis.

The number of alleles detected in each variety significantly differed among loci $(p<0.05$, One-way ANOVA), ranging from 1.8 (ES5) to 3.3 (BPPCT004). Moreover, the number of alleles of the EST-SSRs was significantly lower than the one of SSRs deriving from genomic libraries $(p<0.01$; Student's $t$-test). The main indices of genetic diversity are summarized in Table 2 and are also offered corrected, considering the unknown dosage of the alleles. 
Table 2. Main indices of genetic diversity.

\begin{tabular}{lccccccccc}
\hline Locus SSR & Num All & Num All Geno & Max All & 1-D & Eff num & Eff num & Ho & He & He $^{*}$ \\
\hline BPPCT004 & 17 & 3.3 & 6 & 0.90 & 10.174 & 8.884 & 1.000 & 0.911 & 0.897 \\
BPPCT014 & 24 & 2.5 & 6 & 0.92 & 13.292 & 7.498 & 0.828 & 0.938 & 0.879 \\
BPPCT028 & 13 & 1.9 & 4 & 0.77 & 4.315 & 2.517 & 0.552 & 0.782 & 0.613 \\
EPPISF001 & 9 & 2.4 & 6 & 0.81 & 5.095 & 4.401 & 0.651 & 0.817 & 0.785 \\
EPPISF004 & 10 & 2.3 & 4 & 0.75 & 3.894 & 2.075 & 0.828 & 0.755 & 0.526 \\
EPPISF027 & 6 & 2.1 & 4 & 0.69 & 3.151 & 2.292 & 0.828 & 0.694 & 0.573 \\
ES4 & 6 & 1.8 & 3 & 0.76 & 4.085 & 2.909 & 0.609 & 0.770 & 0.669 \\
ES5 & 11 & 1.8 & 4 & 0.76 & 4.238 & 2.641 & 0.517 & 0.778 & 0.633 \\
PS12A02 & 19 & 2.9 & 5 & 0.92 & 12.639 & 9.185 & 0.793 & 0.932 & 0.902 \\
UDP98409 & 14 & 2.4 & 6 & 0.87 & 7.474 & 5.199 & 0.724 & 0.880 & 0.820 \\
\hline
\end{tabular}

Num All: number of alleles; Num All Geno: average number of alleles per genotype; Max All: maximum number of alleles; 1-D: Simpson Diversity Index; Eff num: effective number of alleles; Ho: Observed heterozygosity; He: Expected Heterozigosity; * index corrected for unknown allelic dosage.

We detected a total of 129 alleles and large differences were present in the number of alleles per locus, which stretched from 6 (EPPISF027 and ES4) to a maximum of 24 (BPPCT014). However, considering the effective number of alleles (i.e., the number of alleles weighted for their frequencies), the most diverse locus was PS12A02. As expected for an hexaploid, clonally propagated and mostly self-incompatible species, the observed heterozygosity (Ho) was very high (on average $0.73 \pm 0.048$ ). Nonetheless, all individuals were heterozygous only at one locus (BPPCT004). The expected heterozygosity was also high and significantly correlated with the number of alleles $(p<0.001$; Spearman's Rho). Under this parameter, the PS12A02 locus is the most informative.

To verify if the diversity observed in our sample does not increase appreciably if an additional marker is added, we built a genotype accumulation curve. This curve illustrates the ability to discriminate between unique genotypes considering an increasing number of molecular markers. The curve reached a plateau at 4 loci (Figure 3), indicating that the number of the employed SSRs is fully adequate to represent the diversity of the germplasm under investigation. The 29 varieties were discriminated by the SSR markers.

\section{Genotype accumulation}

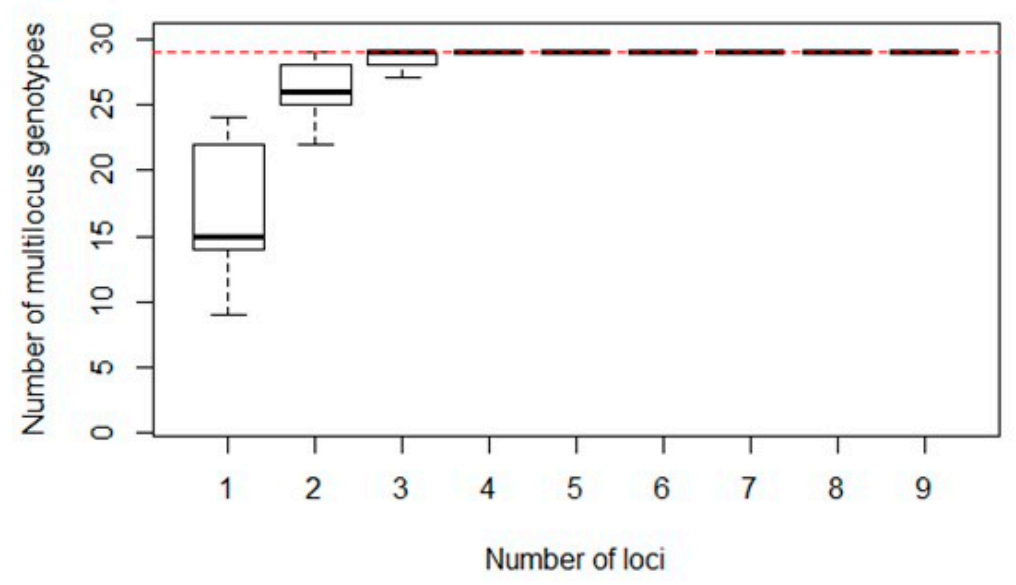

Figure 3. Genotype accumulation plot. The graph shows, for an increasing number of SSR loci, a box-and-whisker plot of the number of multilocus genotype obtained by randomly sampling loci without replacement $(n=1000)$. The band inside the box represents the median (2nd quartile). The dashed red horizontal line denotes the total number of multi-locus genotypes identified in the dataset. Outliers are not showed.

To evaluate the genetic relationship between varieties, we calculated the Bruvo's genetic distance because it permits comparison between individuals with different ploidy levels [39]. The average 
pairwise distance was $0.430 \pm 0.097$, with $3 \%$ (resp., $0.2 \%$ ) of pairwise comparisons having a genetic distance below 0.2 (resp., 0.1), implying a uniformly distributed genetic diversity (Figure 2B). The agglomerative clustering was performed with the UPGMA algorithm and the dendrogram is presented in Figure 4. A clear trend in grouping the varieties was not evident considering the morphological parameters under investigation. For instance, varieties with similar fruit color or size did not clearly agglomerate according to the genetic analysis.

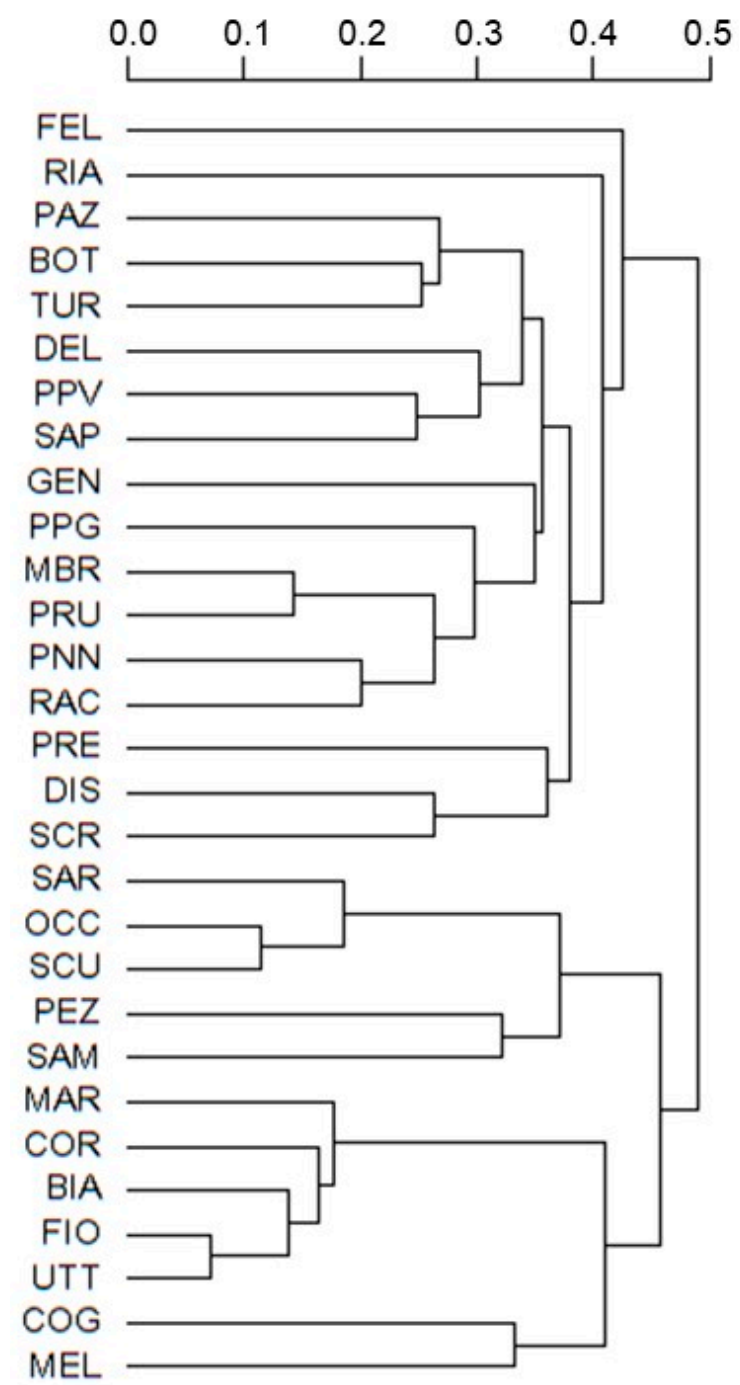

Figure 4. Cluster analysis (UPGMA algorithm based on Bruvo's distances from SSR data) of the European plum varieties.

\subsection{Comparison between Morhological and Genetic Relationships}

The dendrogram based on molecular data failed to identify structures evidenced by morphological analysis. A comparison of the two dendrograms is reported in Supplementary Figure S3 to highlight that the divergent nodes are present at the low hierarchical level. For this reason, to compare the relationships between estimates of resemblances obtained DNA molecular markers and those obtained from morphological descriptors, we calculated the product-moment correlation between the two distance matrices. The correlation was close to zero (0.05) and not significant ( $p=0.16$; Mentel test with 9999 permutations) indicating that the DNA and the morphological analysis sampled a different kind of diversity. 


\section{Discussion}

Traditional orchards are an important element of rural agricultural settings, also influencing biodiversity and gastronomy of local communities [41]. In Italy, as well as in other Western European countries, the area devoted to plum cultivation has largely decreased in the second half of the last century, in conjunction with the decline in the cultivation of traditional European plum varieties. Regrettably, the conservation status of this cultivated germplasm is far from being optimal [12]. Trees of traditional varieties are often insufficiently maintained (e.g., lack of regular pruning), prompting for actions to safeguard biodiversity. Beside financial support, the conservation and revitalisation of the traditional plum varieties need appropriate transfer of knowledge of the germplasm's features. This information is essential to implement conservation-oriented tree maintenance strategies [42] and to increase the appreciation of traditional varieties, at least for local markets and traditional gastronomic products [43].

Our study reported a high level of phenotypic and genetic diversity in the analysed plum germplasm. Specifically, a high number of different phenotypes was scored. It was unexpected that the most common fruit color was light (yellow and yellowish-green). Traditional local varieties of European plum, including those of the Campania region [44], are usually associated with a darker skin color (see also the Bartolomeo Bimbi's portrait "Still life with plums", 1699). Although categorical fruit traits were highly discriminative, quantitative information is needed to distinguish similar varieties. A relatively reduced number of fruit parameters was suitable for differentiating all the varieties. This can be explained considering that the selected phenotypic characters have a clear commercial importance and then, more likely to be object of an (implicit) maintenance breeding. The molecular analysis also indicated a high level of diversity. The SSR loci showed a high number of alleles although locus specific differences were present. The comparison of the allelic diversity with other works is hindered by the use of different analytical techniques, size of the experimental populations, species under investigation, selection of different SSR markers and attention given to the ploidy of the species. Nonetheless, the number of alleles is within the range of variability reported in works analysing wider collections $[18,20,45,46]$. Overall, distinctive DNA profiles could be clearly discerned, without possible cases of synonymy and/or duplicated accessions that can be present in traditional plum germplasm [45,47]. A likely reason is that the analysed germplasm belongs to a curated collection, previously classified based on farmers' description. As expected, the level of heterozygosity was very high. For polyploidy species, the lack of allelic dosage information will cause rare alleles to be over-represented, thus affecting then the calculation of allelic frequency and related parameters (e.g., genetic structure) [48]. The difference between genetic indices calculated with or without an estimation of allelic dosage was modest, which suggests that, for each locus, the proportion of genotypes that are indistinguishable is not high. Our work also indicated that a reduced number of SSRs is sufficient to efficiently discriminate plum varieties [20]. We observed very few high pair-wise similarities (i.e., $>0.9$ ), which is consistent with the lack of sports and/or Essentially Derived Varieties (EDV) originating from formal breeding [49]. A reduced number of nuclear SSRs offers obvious advantages for screening large populations however, we cannot exclude that a higher number of SSRs or the implementation of DNA sequence-based approaches [50], may be necessary to discriminate very similar varieties or to solve cases of putative homonymy.

The comparison between morphological and molecular diversity indicated that morphological descriptors provide information different than the molecular one. In comparison with other works in woody species [51,52], the correlation was virtually non-existent. Considering the genomic and genetic features of $P$. domestica, it is very likely that the DNA markers principally sampled a non-adaptive diversity. This is also corroborated by the fact that the allelic contribution of genomic SSRs to total diversity was significantly higher than that of the EST-markers. An implication of our results is that in plum, the phenotype of a given variety cannot be inferred, even if that variety displays a significant similarity at the DNA marker level with a previously characterized material [53]. Correspondingly, the assignment of trees to a variety based exclusively on morphological similarity could easily increase 
homonymies. Our work indicates that morphological measurements of the fruits are very useful for the description of local varieties, also because their use does not require sophisticated technologies. In addition to the known advantages of molecular fingerprinting, the combination of molecular and morphological data for the classification of traditional plum varieties is probably necessary to separate closely related accessions and sports, or to select variants and clones [49].

\section{Conclusions}

In Western Europe, the cultivation of traditional plum varieties has suffered less compared to whole plum sector and it is experiencing a modest, yet constant, revamp in some regional markets under a pluriactivity paradigm [54]. Our work indicated that the traditional plum varieties of Southern Italy comprise a considerable level of diversity both at the morphological and molecular level, a result that needs to be considered when planning conservation strategies or biodiversity utilization. For instance, it may be difficult to prioritize the varieties to safeguard (e.g., in order to guarantee a wide allelic coverage's conservation) or to promote for further analyses at the agronomic level. Our work implies that both an ex-situ and a regeneration strategy via field cultivation (i.e., aiming at maintenance of integrity) should be preferred to avoid a loss of diversity in traditional European plum varieties [55].

Supplementary Materials: The following are available online at http://www.mdpi.com/2071-1050/11/15/4112/s1, Figure S1: Correlogram (Pearson) of the quantitative variables under investigation. Pairwise correlations are color-mapped according to the color scale of the bar on the right-hand side. Asterisks indicate statistically significant correlations $\left({ }^{*}: p<0.05 ;{ }^{* *}: p<0.01 ;{ }^{* * *}: p<0.001\right)$. Figure S2: Examples of the color classification of the fruit skin (A) and flesh (B). A: 1: yellow; 2: yellowish-green; 3: red; 4: violet blue. B: 1: yellow; 2 yellowish-green, 3: green; 4: orange; 5: reddish-orange; orange; 6: red. Figure S3: A comparison of the hierarchical clustering of the plum varieties using morphological (left) or molecular (right) data. Agglomeration was performed with the UPGMA algorithm for both dendrograms. To ease the comparison, colored lines connect identical names. The different line type in the dendrograms highlights distinct edges in a tree (compared to the other one), Table S1: SSR loci, primer sequences and their main features. Table S2: Frequency $(f)$ and relative frequency (rf) of the categorically scored traits in the germplasm collection.

Author Contributions: Conceptualization, B.B., M.F. and G.C.; methodology, B.B. and G.C.; investigation, R.M., C.C., P.S.; data analysis, R.M., B.B. and G.C.; writing-original draft preparation, G.C.; writing-review and editing, B.B. and G.C.; supervision, B.B., M.F., R.R. and G.C.; funding acquisition, M.F. and R.R.

Funding: This research was funded by the Progetto "SALVE—Salvaguardia della Biodiversità Vegetale della Campania"-PSR Campania 2007/2013 Mis. 214 Azione F2.

Acknowledgments: We thank the Azienda Agricola Sperimentale Regionale Improsta for freely sharing the germplasm.

Conflicts of Interest: The authors declare no conflict of interest

\section{References}

1. Hancock, J.F. Temperate Fruit Crop Breeding: Germplasm to Genomics; Springer Science \& Business Media: Berlin/Heidelberg, Germany, 2008.

2. Chiffolo, A.F.; Hesse, R.W. Cooking with the Bible: Biblical Food, Feasts, and Lore; Greenwood Publishing Group: Westport, CT, USA, 2006.

3. Mariotti, P.; Rossi, F. Agrumi, Frutta e Uve Nella Firenze di Bartolomeo Bimbi, Pittore Mediceo; Consiglio nazionale delle ricerche: Rome, Italy, 1982.

4. Morettini, A. La coltura del susino in Italia-studi e ricerche. Riv. Ortoflorofruttic. Ital. 1968, 52, 385-393.

5. Mugnozza, G.T.S.; Pagnotta, M.A. Italian Contribution to Plant. Genetics and Breeding; Università degli studi della Tuscia: Viterbo, Italy, 1998; p. 922.

6. Sottile, F.; Bellini, E.; Nencetti, V.; Mennone, C.; Peano, C.; Palara, U.; Pirazzini, P.; Mezzetti, B.; Capocasa, F.; Catalano, L. Plum production in Italy: State of the art and perspectives. Acta Hortic. 2010, 874, $25-31$. [CrossRef]

7. Salvioni, C.; Ascione, E.; Henke, R. Structural and economic dynamics in diversified Italian farms. Bio-Based Appl. Econ. 2013, 2, 257-275. 
8. Vávra, R.; Blažek, J.; Mazánek, J.; Bartoníček, L. The economics of modern plum orchards in the Czech Republic. Hortic. Sci. 2006, 33, 47-56. [CrossRef]

9. Ionica, M.E.; Violeta, N.; Trandafir, I.; Cosmulescu, S.; Mihai, B. Physical and chemical properties of some European plum cultivars (Prunus domestica L.). Not. Botan. Horti Agrobot. Cluj-Napoca 2013, 41, 499-503. [CrossRef]

10. Okie, W.; Ramming, D. Plum breeding worldwide. HortTechnology 1999, 9, 162-176. [CrossRef]

11. Chmielewski, F.-M.; Götz, K.-P.; Weber, K.C.; Moryson, S. Climate change and spring frost damages for sweet cherries in Germany. Int. J. Biometeorol. 2018, 62, 217-228. [CrossRef]

12. Rallo, P.; Jiménez, M.R.; Casanova, L.; Morales-Sillero, A.; Suárez, M.P. Genetic Diversity of Stone Fruit Cultivars Preserved On-Farm in Southern Spain. J. Agric. Sci. Technol. 2019, 21, 943-955.

13. Kole, C.; Abbott, A.G. Genetics, Genomics and Breeding of Stone Fruits; CRC Press: Boca Raton, FL, USA, 2012.

14. Montevecchi, G.; Masino, F.; Antonelli, A.; D'Antuono, L.F.; Bignami, C. Sugar content and profile of Zucchella and Ramassin, local Italian plums used for no-added sugar traditional jam manufacturing. In Proceedings of the 4th International Symposium on Traditional Foods from Adriatic to Caucasus, Kyrenia, Cyprus, 19-21 April 2018; p. 309.

15. Esquinas-Alcázar, J. Protecting crop genetic diversity for food security: Political, ethical and technical challenges. Nat. Rev. Genet. 2005, 6, 946-953. [CrossRef]

16. Khoury, C.; Laliberté, B.; Guarino, L. Trends in ex situ conservation of plant genetic resources: A review of global crop and regional conservation strategies. Genet. Resour. Crop. Evol. 2010, 57, 625-639. [CrossRef]

17. Sarigu, M.; Grillo, O.; Bianco, M.L.; Ucchesu, M.; d’Hallewin, G.; Loi, M.C.; Venora, G.; Bacchetta, G. Phenotypic identification of plum varieties (Prunus domestica L.) by endocarps morpho-colorimetric and textural descriptors. Comput. Electron. Agric. 2017, 136, 25-30. [CrossRef]

18. Baraket, G.; Abdallah, D.; Mustapha, S.B.; Tamarzizt, H.B.; Salhi-Hannachi, A. Combination of Simple Sequence Repeat, S-Locus Polymorphism and Phenotypic Data for Identification of Tunisian Plum Species (Prunus spp.). Biochem. Genet. 2019, 1-22. [CrossRef] [PubMed]

19. Claverie, M.; Bosselut, N.; Lecouls, A.; Voisin, R.; Lafargue, B.; Poizat, C.; Kleinhentz, M.; Laigret, F.; Dirlewanger, E.; Esmenjaud, D. Location of independent root-knot nematode resistance genes in plum and peach. Theor. Appl. Genet. 2004, 108, 765-773. [CrossRef] [PubMed]

20. Decroocq, V.; Hagen, L.; Favé, M.-G.; Eyquard, J.-P.; Pierronnet, A. Microsatellite markers in the hexaploid Prunus domestica species and parentage lineage of three European plum cultivars using nuclear and chloroplast simple-sequence repeats. Mol. Breed. 2004, 13, 135-142.

21. Reales, A.; Sargent, D.J.; Tobutt, K.R.; Rivera, D. Phylogenetics of Eurasian plums, Prunus, L. section Prunus (Rosaceae), according to coding and non-coding chloroplast DNA sequences. Tree Genet. Genomes 2010, 6, 37-45. [CrossRef]

22. Horvath, A.; Balsemin, E.; Barbot, J.-C.; Christmann, H.; Manzano, G.; Reynet, P.; Laigret, F.; Mariette, S. Phenotypic variability and genetic structure in plum (Prunus domestica L.), cherry plum (P. cerasifera Ehrh.) and sloe (P. spinosa L.). Sci. Hortic. 2011, 129, 283-293. [CrossRef]

23. Rao, R.; La Mura, M.; Corrado, G.; Ambrosino, O.; Foroni, I.; Perri, E.; Pugliano, G. Molecular diversity and genetic relationships of southern Italian olive cultivars as depicted by AFLP and morphological traits. J. Hortic. Sci. Biotechnol. 2009, 84, 261-266. [CrossRef]

24. Corrado, G.; Caramante, M.; Piffanelli, P.; Rao, R. Genetic diversity in Italian tomato landraces: Implications for the development of a core collection. Sci. Hortic. 2014, 168, 138-144. [CrossRef]

25. Baldini, E. Contributo allo studio delle cultivar di susino. Riv. Ortoflorofruttic. Ital. 1958, 42, 390-423.

26. Wei, T.; Simko, V.; Levy, M.; Xie, Y.; Jin, Y.; Zemla, J. Package 'corrplot'. Statistician 2017, 56, 316-324.

27. Gower, J.C. A general coefficient of similarity and some of its properties. Biometrics 1971, 857-871. [CrossRef]

28. D'Orazio, M. Statistical Matching and Imputation of Survey Data with StatMatch; Italian National Institute of Statistics: Rome, Italy, 2017.

29. RC Team. R: A language and environment for statistical computing. Computing 2013. [CrossRef]

30. Verdone, M.; Rao, R.; Coppola, M.; Corrado, G. Identification of zucchini varieties in commercial food products by DNA typing. Food Control. 2018, 84, 197-204. [CrossRef]

31. Dirlewanger, E.; Cosson, P.; Tavaud, M.; Aranzana, M.; Poizat, C.; Zanetto, A.; Arús, P.; Laigret, F. Development of microsatellite markers in peach [Prunus persica (L.) Batsch] and their use in genetic diversity analysis in peach and sweet cherry (Prunus avium L.). Theor. Appl. Genet. 2002, 105, 127-138. [CrossRef] [PubMed] 
32. Vendramin, E.; Dettori, M.; Giovinazzi, J.; Micali, S.; Quarta, R.; Verde, I. A set of EST-SSRs isolated from peach fruit transcriptome and their transportability across Prunus species. Mol. Ecol. Notes 2007, 7, 307-310. [CrossRef]

33. Li, X.; Shangguan, L.; Song, C.; Wang, C.; Gao, Z.; Yu, H.; Fang, J. Analysis of expressed sequence tags from Prunus mume flower and fruit and development of simple sequence repeat markers. BMC Genet. 2010, 11, 66. [CrossRef]

34. Downey, S.L.; Iezzoni, A.F. Polymorphic DNA markers in black cherry (Prunus serotina) are identified using sequences from sweet cherry, peach, and sour cherry. J. Am. Soc. Hortic. Sci. 2000, 125, 76-80. [CrossRef]

35. Cipriani, G.; Lot, G.; Huang, W.-G.; Marrazzo, M.; Peterlunger, E.; Testolin, R. AC/GT and AG/CT microsatellite repeats in peach [Prunus persica (L) Batsch]: Isolation, characterisation and cross-species amplification in Prunus. Theor. Appl. Genet. 1999, 99, 65-72. [CrossRef]

36. Scarano, D.; Rubio, F.; Ruiz, J.J.; Rao, R.; Corrado, G. Morphological and genetic diversity among and within common bean (Phaseolus vulgaris L.) landraces from the Campania region (Southern Italy). Sci. Hortic. 2014, 180, 72-78. [CrossRef]

37. Nei, M. Estimation of average heterozygosity and genetic distance from a small number of individuals. Genetics 1978, 89, 583-590.

38. Meirmans, P.G.; Van Tienderen, P.H. GENOTYPE and GENODIVE: Two programs for the analysis of genetic diversity of asexual organisms. Mol. Ecol. Notes 2004, 4, 792-794. [CrossRef]

39. Bruvo, R.; Michiels, N.K.; D'Souza, T.G.; Schulenburg, H. A simple method for the calculation of microsatellite genotype distances irrespective of ploidy level. Mol. Ecol. 2004, 13, 2101-2106. [CrossRef] [PubMed]

40. Kamvar, Z.N.; Tabima, J.F.; Grünwald, N.J. Poppr: An R package for genetic analysis of populations with clonal, partially clonal, and/or sexual reproduction. PeerJ 2014, 2, e281. [CrossRef] [PubMed]

41. Horak, J.; Peltanova, A.; Podavkova, A.; Safarova, L.; Bogusch, P.; Romportl, D.; Zasadil, P. Biodiversity responses to land use in traditional fruit orchards of a rural agricultural landscape. Agric. Ecosyst. Environ. 2013, 178, 71-77. [CrossRef]

42. Berkes, F.; Folke, C.; Gadgil, M. Traditional ecological knowledge, biodiversity, resilience and sustainability. In Biodiversity Conservation; Springer: Berlin/Heidelberg, Germany, 1994; pp. 269-287.

43. Mulder, M.B.; Coppolillo, P. Conservation: Linking Ecology, Economics, and Culture; Princeton University Press: Princeton, NJ, USA, 2005.

44. Santangelo, I. La Frutta Della Campania; Imago Media S.R.L.: Dragoni, CE, Italy, 2009.

45. Kazija, D.H.; Jelačić, T.; Vujević, P.; Milinović, B.; Čiček, D.; Biško, A.; Pejić, I.; Šimon, S.; Mihaljević, M.Ž.; Pecina, M. Plum germplasm in Croatia and neighboring countries assessed by microsatellites and DUS descriptors. Tree Genet. Genomes 2014, 10, 761-778. [CrossRef]

46. Makovics-Zsohár, N.; Tóth, M.; Surányi, D.; Kovács, S.; Hegedûs, A.; Halász, J. Simple Sequence Repeat Markers Reveal Hungarian Plum (Prunus domestica L.) Germplasm as a Valuable Gene Resource. HortScience 2017, 52, 1655-1660. [CrossRef]

47. Sehic, J.; Nybom, H.; Hjeltnes, S.; Gaši, F. Genetic diversity and structure of Nordic plum germplasm preserved ex situ and on-farm. Sci. Hortic. 2015, 190, 195-202. [CrossRef]

48. Dufresne, F.; Stift, M.; Vergilino, R.; Mable, B.K. Recent progress and challenges in population genetics of polyploid organisms: An overview of current state-of-the-art molecular and statistical tools. Mol. Ecol. 2014, 23, 40-69. [CrossRef]

49. Gharbi, O.; Wünsch, A.; Rodrigo, J. Characterization of accessions of 'Reine Claude Verte'plum using Prunus SRR and phenotypic traits. Sci. Hortic. 2014, 169, 57-65. [CrossRef]

50. Zhebentyayeva, T.; Shankar, V.; Scorza, R.; Callahan, A.; Ravelonandro, M.; Castro, S.; DeJong, T.; Saski, C.A.; Dardick, C. Genetic characterization of worldwide Prunus domestica (plum) germplasm using sequence-based genotyping. Hortic. Res. 2019, 6, 12. [CrossRef]

51. Corrado, G.; La Mura, M.; Ambrosino, O.; Pugliano, G.; Varricchio, P.; Rao, R. Relationships of Campanian olive cultivars: Comparative analysis of molecular and phenotypic data. Genome 2009, 52, 692-700. [CrossRef] [PubMed]

52. Pop, I.F.; Vicol, A.C.; Botu, M.; Raica, P.A.; Vahdati, K.; Pamfil, D. Relationships of walnut cultivars in a germplasm collection: Comparative analysis of phenotypic and molecular data. Sci. Hortic. 2013, 153, 124-135. [CrossRef] 
53. Nuel, G.; Robin, S.; Baril, C. Predicting distances using a linear model: The case of varietal distinctness. J. Appl. Stat. 2001, 28, 607-621. [CrossRef]

54. Ortiz-Miranda, D.; Moragues-Faus, A.; Arnalte-Alegre, E. Agriculture in Mediterranean Europe: Between Old and New Paradigms; Emerald Group Publishing Limited: Bingley, UK, 2013.

55. Lawrence, M. A comprehensive collection and regeneration strategy for ex situ conservation. Genet. Resour. Crop Evol. 2002, 49, 199-209. [CrossRef]

(C) 2019 by the authors. Licensee MDPI, Basel, Switzerland. This article is an open access article distributed under the terms and conditions of the Creative Commons Attribution (CC BY) license (http://creativecommons.org/licenses/by/4.0/). 